\title{
COMMENT
}

\section{Nothing to do and all day to do it in}

\author{
Gregory A Petsko*1
}

\author{
Too much work, and no vacation, \\ Deserves at least a small libation. \\ So hail! my friends, and raise your glasses, \\ Work's the curse of the drinking classes.
}

Oscar Wilde

With me a change of trouble is as good as a vacation.

David Lloyd George

There is probably no more obnoxious class of citizen, taken end for end, than the returning vacationist.

Robert Benchley

Sitting on the deck of the summer house, admiring the way the late afternoon sun dappled the surface of the bay in the distance, I hadn't a care in the world. (Well, actually, I had several, but I was doing my best to forget about them.) The dogs had just finished taking me for a long walk, the heat of the day had given way to a comfortable breeze, I had managed to avoid doing any major chores around the place, a cool drink had perched itself on the arm of my chair - all in all, life felt pretty good. At such times the mind can afford the luxury of wandering, and mine did. Later, when I realized my column was due, I had the choice of dragging it back, or of sharing with you the places it visited. Guess which option I picked?

\section{What's in a name?}

Headline in this morning's London Times: "Rebels breach Gaddafi compound".

Headline in this morning's Los Angeles Times: "Blasts rattle Tripoli as Libyan rebels encircle Kadafi compound".

Headline in this morning's Chicago Sun-Times: "Gadhafi son rallies supporters; rebels control most of Tripoli".

Headline in this morning's New York Times: "Qaddafi's Rule Crumbling as Loyalists Fight On in Tripoli".

Headline in this morning's Boston Globe, which is owned by the same news agency: "Rebels try to stamp out Loyalists, Khadafy at large".

*Correspondence: petsko@brandeis.edu

'Rosenstiel Basic Medical Sciences Research Center, Brandeis University, Waltham, MA 02454-9110, USA
Headline in this morning's Le Monde: "Les insurgés ont pénétré dans le quartier général de Kadhafi à Tripoli".

Headline in this morning's Neue Zürcher Zeitung: "Erste Ghadhafi-Kämpfer ergeben sich".

Headline in The Sun this morning: "Winslet flees inferno on Branson's $£ 90$ million island".

OK, what did you expect from The Sun? But look at the others.

During the Arab Spring, which is now the Arab Summer, I have seen every permutation imaginable. First letters have varied from $\mathrm{G}$ to $\mathrm{Q}$ to $\mathrm{K}$ - sometimes with a following $\mathrm{H}$, sometimes without. The $\mathrm{H}$ has also made appearances in various positions in the middle of the name, an area also populated, seemingly randomly, by one or more Ds and Fs. Not to be outdone, the last letter has also ranged from $\mathrm{Y}$ to $\mathrm{I}$ and, in one memorable instance, YI. Once I saw two completely different spellings in the same newspaper. All of which raises an interesting question: when the rebels finally capture him, how do they know they have the right man: Moammar Quaddhafi or 'Mu'ammar' Kadafy?"

\section{Random thoughts}

Speaking of randomness, a recent article in Nature Reviews Drug Discovery (2011, 10:507-519 "How were new medicines discovered?") reports that, out of the 259 agents that were approved by the US Food and Drug Administration between 1999 and 2008, 75 were first-in-class drugs with new molecular mechanisms of action (MMOAs, that is to say, new targets, basically), and out of these, 50 (67\%) were small molecules and 25 (33\%) were biologics. The results also show that the contribution of phenotypic screening to the discovery of first-in-class small-molecule drugs exceeded that of target-based approaches - with 28 and 17 of these drugs coming from the two approaches, respectively. The authors state that this difference occurred "in an era in which the major focus was on targetbased approaches". They go on to postulate "that a targetcentric approach for first-in-class drugs, without consideration of an optimal MMOA, may contribute to the current high attrition rates and low productivity in pharmaceutical research and development." Nature Medicine promptly published a short piece on the paper with the catchy title, "Random screening trumps targeted drug design" (2011, 17:911). 
There are two problems with that, as I see it. The first is that it is not at all clear to me that, during the period in question, the major focus was on target-based approaches. It may have been so in cancer drug discovery (I call this the Gleevec effect), but my experience in consulting with a lot of biotech and pharmaceutical companies was that random screening was the major focus in most projects for most of that decade. Assuming that targeted efforts predominated may give too much weight to the impact of the human genome sequence and other genomics-based programs; true, they did produce 'targets' in abundance, but almost none were validated targets and an industry suddenly awash in targets of uncertain value was, if anything, more likely, I think, to fall back on cell-based screens that didn't necessarily require a specific target. My point is that it is crucial to establish what the dominant approaches really were if you're going to conclude what Nature Medicine concluded, because the issue is not how many new drugs came out of each approach, it's how many came out of each approach relative to the total number of projects that used each approach. If you don't have that information, you may end up making the same mistake you would make in concluding that white sheep are dumber than black sheep because more of them are hit by cars, without taking into account that there are a hell of a lot more white sheep, period.

The second problem I have is that recent data may contradict the whole notion that the industry suffers from "high attrition rates and low productivity". This year is poised to produce a bumper crop of new approved drugs, probably the highest number since the AIDS drug boom of the 1990s. Most of these new drugs were found by targeted approaches. Many of the more thoughtful pharmaceutical researchers I know have turned sour on random screening - at least of non-natural-product libraries - and are rediscovering targeted drug design. To be fair, a detailed reading of the original article would reveal a more balanced discussion than that suggested by the Nature Medicine news piece, so one moral might be, "Always read the original paper". But a second moral would seem to be that it is very dangerous to draw conclusions about today from studies of yesterday when things today change as fast as they do.

\section{The friendlier skies?}

Speaking of change, it seems change of sorts may be coming to air travel. One of the real problems with being a biologist of any kind, but especially a genome biologist, is that our increasingly international field means you have to travel a lot for business, and anyone who travels a lot for business will almost certainly become reluctant to travel for pleasure. Air travel in particular is the modern equivalent of the ancient Chinese sport of pulling out the fingernails, one by one. So I was delighted this morning when I saw a news feed that indicated a new set of airline passenger rights had just gone into effect in the US. (Amazing: passengers have rights. Who knew?) One change is that passengers involuntarily bumped from oversold flights are now eligible for more money. Under the new rule, bumped passengers can get up to $\$ 650$ if the airline can get them to their destination within a short period of time (within 1-2 hours of their originally scheduled arrival time for domestic flights), or up to $\$ 1,300$ if they are delayed for a long time. Previously, the amounts were capped at $\$ 400$ and $\$ 800$, respectively.

My advice would be to always take the cash rather than flight vouchers, which they offer first. After all, if you take a flight voucher, you are accepting an opportunity for that airline to stick it to you again.

In the second big change, international flights finally get a tarmac delay limit - sort of. International flights stuck on US airport tarmacs for more than 4 hours must now allow passengers to get off the plane or face huge fines, with exceptions allowed for safety, security or airtraffic-control-related reasons. That sounds like a good thing until you realize two other things: (1) the limit used to be 12 hours! I wouldn't even want to do something fun for 12 hours. (2) The limit is still 4 hours. 4 hours of unmitigated hell.

Finally, if you pay extra to check in a piece of luggage and the airline loses your bag, it must now refund the bag fee. That's right, until now, they could both lose your luggage and charge you for the privilege.

So I suppose all this is an improvement of some sort, in that we have gone from having the rights of galley slaves to having the rights of - well, a higher class of galley slaves. But the moral, I think, is that if God had intended Man to fly, He would have never have given us the airlines.

\section{Too good to pass up}

Speaking of morals, another important one is never to give a wise-guy a golden opportunity. I was idly looking over my emails (I feel no compulsion to answer them while on vacation, but I've never been able to stop looking at them) when I saw a message from one of my best friends, also a scientist. He wanted me to read over an author's lay summary of a paper he was submitting (the journal has a requirement for such author summaries, and they must be approved by someone not an author of the paper). Probably because of this column, I often get asked to do that sort of thing, and this one was no trouble the science was excellent, and he writes beautifully - but the email was what caught my attention. What he meant to ask me was for a statement that the author summary was OK; what he wrote was: "At this point an email commenting that the author is OK is all I need."

Well, that was like giving Moammar (Muhamar? Mu'ammar?) Qadhafi (Khadafi? Gadaffy?) access to 
weapons of mass destruction. I immediately composed an email to the editor of the journal, who knows us both, with a cc to my friend. I quoted his exact message at the top and then wrote, "I regret to say that, on the basis of thirty years of friendship, I cannot in good conscience attest that the author is OK."

I hit 'Send', closed the lid on my MacBook Air, and sank back in my deck chair. The sun had almost set, and the sky was a Turner canvas of purple and red. I heaved a deep sigh of contentment. The perfect end to a perfect vacation day.

\section{Note}

Variants in spelling can arise from different transliterations from the Arabic.

See: http://en.wikipedia.org/wiki/

Muammar_Gaddafi\#Transliteration_of_his_Arabic_ name

Published: 31 August 2011

doi:10.1186/gb-2011-12-8-126

Cite this article as: Petsko GA: Nothing to do and all day to do it in. Genome Biology 2011, 12:126. 